\title{
Tohtoriopintojen monet merkitykset suomalaisille ja ulkomaalaisille jatko-opiskelijoille
}

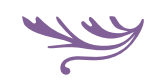

Ulkomaalaiset tohtoriopiskelijat tähtäävät suomalaisia määrätietoisemmin akateemiselle uralle, osoittaa jatko-opiskelijoiden teemahaastatteluihin pohjaava tutkimus. Jatko-opiskelijat jakaantuvat kolmeen tyyppiin: tieteellisen uran tavoittelijoihin, kilpailun paineessa epäröijiin ja itsellisiin sivistyjiin.

\section{$\mathbf{y}$}

SUOMALAINEN KORKEAKOULUPOLITIIKKA korostaa kansainvälisten linjausten (EU 2020; Kehm 2007) mukaisesti tutkimuksen yhteiskunnallista merkitystä ja markkina-arvoa. Yliopistoja kannustetaan profiloitumaan kilpailukykyämme edistäviksi tutkimusyliopistoiksi (OKM 2015). Uudenlaiset trendit ja arvot, kuten aiemmin lähinnä yritysmaailmaan liitetty ansaintalogiikka ja tehokkuusvaatimukset, ovat nousseet perinteisemmän akateemisen kulttuurin rinnalle (Henkel 2004; Rinne \& Jauhiainen 2012; Slaughter \& Leslie 1997). Tämä näkyy konkreettisesti esimerkiksi jatkuvana hankekilpailuna ja projekti- luonteisten pätkätöiden lisääntymisenä (Hakala 2009).

Tehostamistrendit näkyvät myös suomalaisessa tohtorikoulutuksessa, jota on uudistettu yhä tehokkaampaan, kansainvälisempään, tuloksellisempaan ja ammattimaisempaan suuntaan (Suomen Akatemia 2011). Tohtorikoulutus on liitetty yhä tiiviimmin korkeakoulu- ja tiedepolitiikkaan, sillä tohtoriopiskelijat tekevät merkittävän osan tieteellisestä tutkimuksesta (Hakala 2009). Tutkintojen yhtenäistämiseen tähtäävän Bolognan prosessin myötä tohtoriopinnoista on tehty kandidaatin ja maisterin 
NYKYINEN TOHTORIKOULUTUS

TAVOITTEINEEN JA

K ̈̈YT ̈̈NTEINEEN PERUSTUU

YḦ̈ ENEMM $\ddot{A} N$ KOVIEN

TIETEIDEN TRADITIOON.

tutkinnoista muodostuvan kaksiportaisen tutkintojärjestelmän kolmas vaihe (Hiltunen \& Pasanen 2006).

Tohtoriopiskelijamäärät ovat voimakkaasti kasvaneet. Vuonna 2016 Suomessa oli runsaat 18000 tohtoriopiskelijaa, ja tohtorintutkintoja suoritettiin lähes 1 900, kolme kertaa enemmän kuin vuonna 1993 (OPM 2004; Vipunen 2017a). Suoritetut tohtorintutkinnot ovat vuodesta 1995 asti toimineet yhtenä yliopistojen rahoitusperusteena (Hakala 2009), mikä korkeakoulutuksen massoittumisen ohella selittää kasvua (Trow 1973; Vuolanto, Pasanen \& Aittola 2006). Vuoteen 2017 asti rahoitusmallissa huomioitiin ulkomaalaisten suorittamien tohtorintutkintojen osuus (OKM 2015), mikä näkyy kasvavana ulkomaalaisten tohtoriopiskelijoiden määränä: vuonna 2016 heitä oli jo yli 3600 (Vipunen 2017b).

Korkeakoulupoliittiset tulos- ja tehokkuuspainotteiset linjaukset heijastuvat jatko-opiskeluympäristöön ja yksilöiden toimintaan esimerkiksi siten, että ne lisäävät kilpailua (Hannukainen \& Brunila 2017; Kouhia \& Tammi 2014; Vuolanto ym. 2006). Tehokkuutta tulee osoittaa julkaisuin, jotka Julkaisufoorumin tasoluokituksin toimivat yhtenä niin yliopistojen kuin yksilöidenkin tuloksellisuuden mittarina (OKM 2015; Hannukainen \& Brunila 2017). Lisäksi työuran tavoittelu on nostettu keskiöön, mutta samalla tohtorien työttömyys on lisääntynyt (OKM 2016).

Nykyinen tohtorikoulutus tavoitteineen ja käytänteineen edustaa politiikkaa, joka perustuu yhä enemmän kovien tieteiden (Becher 1989), kuten luonnontieteiden ja lääketieteen, traditioille. Tohtoriksi opiskelemisen merkitys väistämättä muuttuu, ja siksi on kiinnostavaa selvittää, miten tohtoriopiskelijat jatko-opintojaan tulkitsevat. Ulkomaalaisille tohtoriopiskelijoille oman haasteensa tuovat opiskelu ja eläminen vieraassa maassa ja kulttuurissa (Fotovatian 2012).

Tarkastelemme humanistisen, yhteiskuntatieteellisen ja kasvatustieteiden tohtoriohjelmissa opiskelevien suomalaisten ja ulkomaalaisten käsityksiä tohtoriksi opiskelusta. Käsitysten muodostumisessa merkittäviä ovat arviot itsestä suhteessa tulevaisuuteen ja uraan (ks. esim. McAlpine \& Turner 2012). Kysymme, miten tohtoriopiskelijat suuntautuvat opintoihinsa ja tutkinnon jälkeiseen työhön. Ymmärrämme suuntautumisella sekä itse tohtoriksi opiskelua että näkemyksiä sen jälkeisestä urasta ja tulevaisuudesta tohtorina.

Aiemmin tohtoriksi opiskelemista eli tohtoroitumista muuttuvassa toimintaympäristössä on tutkittu esimerkiksi identiteetin (esim. Archer 2008; Hakala 2009), sosialisaation, akateemisen tietokapitalismin sekä tähän kytkeytyvän hallinnan teorian (esim. Kouhia \& Tammi 2014; Mendoza 2007; Hannukainen \& Brunila 2017) näkökulmista. Tohtoriopiskelijan ja tiedeyhteisön väliseen vuorovaikutukseen perehtynyt Jenni Stubb (2012) on tutkinut tohtoriopiskelijoiden käsityksiä tohtoroitumisesta ja tutkijayhteisöstä ja käsitysten yhteyttä hyvinvointiin.

Tohtoriopiskelijoiden urasuuntautumista ja -odotuksia on tutkittu ulkomailla ja Suomessa (esim. McAlpine \& Turner 2012; Sauermann \& Roach 2012). Meillä tutkimukset ovat perustuneet lähinnä kyselyaineistoihin (Isohätälä, Louis, Mikkonen \& Pyhältö 2016; Vuolanto ym. 2006). Ulkomaalaisten opiskelijoiden kokemusta tohtoriopinnoista ja tulevaisuuden uraan suuntautumista on tutkittu kansainvälisesti (esim. Harman 2003; Ugwu \& Adamuti-Trache 2017), mutta Suomessa tohtorikoulutuksessa olevia ulkomaalaisia opiskelijoita huomattavasti vähemmän (Sakurai 2014; Sakurai, Vekkaila \& Pyhältö 2017). Suomessa tohtoriopiskelijoita on lisäksi tutkittu esimerkiksi elämänkulun ja sukupuolen (Maunula 2014; Peura 2008), ohjauksen (Aittola 1995), valikoitumisen (Jauhiainen \& Nori 2017) sekä työllistymisen (Sainio \& Carver 2016) näkökulmista. 
Kilpailu tohtoriohjelmista

JA NIIDEN RAHOITUKSESTA

ON SIIRTYNYT YLIOPISTOJEN

SISÄLLE.

\section{TEHOSTUVA TOHTORIKOULUTUS}

Aiemmin tohtorikoulutusta Suomessa kuten monissa muissakin maissa luonnehti humboldtilainen akateeminen vapaus. Käsite tulee saksalaisen Wilhelm von Humboldtin 1800-luvun alussa muotoilemasta sivistysyliopiston aatteesta. Käytännössä se tarkoitti sitä, että tutkijaksi kasvettiin varsin itsenäisesti, kokeneen mestarin - usein löyhässä - ohjauksessa. Tiede, sivistys ja yksilön kasvu asettuivat yhteiskunnallisen ja taloudellisen hyödyn edelle. (Laiho 1997; Pritchard 2004; Kehm 2007.)

Suomessa tieteellistä jatkokoulutusta alettiin systemaattisesti ja laaja-alaisesti kehittää 1980- ja 1990-lukujen vaihteessa. Vuonna 1995 tohtorikoulutuksen tehostamiseksi ja laadun parantamiseksi perustettiin valtakunnallinen tutkijakoulujärjestelmä perinteisen jatkokoulutuksen rinnalle (Aittola 1995; Husso 2005). Tämän myötä jatkoopinnot muuttuivat aiempaa tavoitteellisempaan, suunnitelmallisempaan ja koulumaisempaan suuntaan (Aittola \& Määttä 1998).

Uudistuksilla tavoiteltiin lisää tohtoreita, jotka valmistuisivat yhä nuorempina yhteiskunnan käyttöön. Palkallisia tutkijakoulutuspaikkoja myöntämällä tuettiin päätoimista jatko-opiskelua valmistumisaikojen lyhenemisen ja väittelyiän alenemisen toivossa. Tohtorien määrä lisääntyi, mutta valmistumisajat eivät lyhentyneet. (Aittola \& Määttä 1998; Hiltunen \& Pasanen 2006.) Suositukset liittää hajanainen tutkijakoulutus yhä kiinteämmin yliopistojen tutkimusstrategioihin sekä lisätä tohtoriopiskelijoiden määrää, monitieteisyyttä, kansainvälisyyttä ja yhteistyötä elinkeinoelämän kanssa johtivat lopulta nykyisten yliopistokohtaisten tutkijakoulujen perustamiseen, jotka aloittivat toimintansa vuonna 2014 (Niemi ym. 2011; Suomen Akatemia 2011).

Nykyisessä järjestelmässä jokainen tohtoriopiskelija kuuluu yliopistonsa tutkijakouluun ja johonkin sen tohtoriohjelmaan. Muutosten myötä tohtorikoulutuksen on kuvattu muistuttavan yhä enemmän perustutkinto-opintoja kurssisuorituksineen ja sääntöineen (Sariola 2017). Opiskelu tohtoriohjelmissa on aiempaa säädellympää, sillä tutkinnon tavoiteaika on puristettu neljään vuoteen. Todellisuudessa tohtorintutkinnon suoritusajat ovat toistaiseksi pysyneet pidempinä (OKM 2018).

Tohtorikoulutus on myös entistä ammattimaisempaa. Siinä on alettu kiinnittää yhä enemmän huomiota työelämävalmiuksien laajentamiseen, sillä tohtorien halutaan sijoittuvan yliopiston lisäksi yksityisen ja julkisen sektorin asiantuntija- ja kehitystehtäviin, kolmannelle sektorille sekä yrittäjiksi. Ammattimaisuutta korostaa neliportainen tutkijanuramalli, jolla pyritän edistämään tuoreen tohtorin matkaa ammattitutkijuuteen. Tohtoroituminen sijoittuu mallin ensimmäiselle portaalle, tutkijatohtori toiselle, yliopistonlehtori kolmannelle ja professori ylimmälle. (OKM 2016.)

Nykyisten tavoitteiden mukaan tohtorintutkinnon tulee olla ponnahduslauta tutkijanuralle, ei enää sen huipennus (Henkel 2004). Ammattitutkijuus tarkoittaa myös kansainvälistymistä, johon kannustetaan edistämällä tutkijoiden liikkuvuutta Suomesta ulkomaille ja päinvastoin.

Toisin kuin 1990-luvulla perustetuissa valtakunnallisissa tutkijakouluissa, taloudellinen vastuu on nyt kokonaan yliopistoilla, ja kilpailu tohtoriohjelmista ja niiden rahoituksesta on siirtynyt yliopistojen sisälle. Tohtoriohjelmissa niukoista resursseista kilpailee aikaisempaa isompi ja heterogeenisempi joukko (Jauhiainen \& Nori 2017), ja palkalliseen tohtorikoulutuspaikkaan on mahdollisuus vain joillakin. Jatko-opiskelijat suorittavat tutkintoaan erilaisin rahoitusjärjestelyin, kuten märääaikaisena projektityöntekijänä, apurahan turvin tai muun työn ohessa.

Yliopistojen rahoitusmalli ruokkii tohtorituotantoa, mutta tehostaminen luo painetta tutkinnon jälkeisen eli post doc -vaiheen mahdollisuuksiin. 


\section{TUTKIJAN ON JATKUVASTI}

\section{OSOITETTAVA}

\author{
KYVYKKYYTENS $\ddot{A}$ \\ JULKAISUIN.
}

Akateemisen uran luominen väittelyn jälkeen on käynyt aiempaa vaikeammaksi, kun yliopistojen kokonais- ja perusrahoitus on viime vuosina systemaattisesti laskenut (Seuri \& Vartiainen 2018) ja kilpailu tutkimusrahoituksesta sekä post doc -tehtävistä on kiristynyt. Yliopiston porttien käytyä yhä ahtaammiksi tohtoriksi opiskelun merkitys on vääjäämättä muuttunut akateemisuuden uusintamisesta kohti moninaistuvia ja yhä ennakoimattomampia urapolkuja (Henkel 2004; Kehm 2007).

\section{UUDELLEEN MÄÄRITTYVÄ TOHTORIUS}

Perinteisesti tohtorikoulutuksen keskeisin tehtävä on ollut akateemisuuden uusintaminen (Henkel 2004). Tohtoriopiskelijat ovat sosiaalistuneet tiedeyhteisön yhteisesti jakamien arvojen, kuten vapauden, tutkijan autonomian ja yhteisöllisyyden, (Henkel 2004; Ylijoki \& Ursin 2013) lisäksi edustamansa tieteenalan heimokulttuuriin. Tällaiset paljolti humboldtilaiseen yliopistoideaaliin (esim. Pritchard 2004) liitetyt arvot ja käytännöt ovat olleet ominaisia pehmeillä tieteenaloilla, kuten humanistisissa ja yhteiskuntatieteellisissä, joilla opiskelu on perinteisesti ollut itsenäistä ja ajoittain yksinäistäkin. Luonnontieteissä opiskelu on ollut kurssimuotoisempaa ja tutkimusympäristöt ryhmäpainotteisia ja verkottuneita. (Laiho 1997.) Myös eri tieteenalojen julkaisukäytännöt ovat olleet erilaiset, kovissa tieteissä on suosittu ryhmämuotoista julkaisemista, pehmeillä aloilla yksin julkaiseminen on yleisempää (Valo 2013).

Uravaihtoehtojen näkökulmasta tohtoriksi valmistuminen on monimerkityksellinen, ristiriitainenkin. Yhtältä tutkintoa on uudistettu yhä konkreettisemmin tutkijanammattiin valmistavaksi, mutta varsinainen ammattitutkinto se ei ole. Toisaalta tohtorintutkinnon halutaan maisterintutkinnon tavoin nähdä valmentavan mitä erilaisimpiin yhteiskunnan asiantuntijatehtäviin, yhä enemmän myös yksityiselle sektorille sekä yrittäjiksi. Toistaiseksi tohtoreiden sijoittumien yliopistojen ulkopuolelle ei ole kuitenkaan sanottavasti lisääntynyt.

Yliopistojen työelämä- ja urapalveluiden Aarresaari-verkoston uraseurantakyselyn (2016) mukaan vuosina 2012-2013 valmistuneista tohtoreista 40 prosenttia oli työllistynyt yliopistoihin vuonna 2015. Yksityisellä sektorille työskenteli joka neljäs, saman verran kuin valtion ja kuntien palveluksessa yhteensä. Kolmannelle sektorille sijoittui ainoastaan vajaat kahdeksan prosenttia tuoreista tohtoreista. Ulkomaalaisten tohtorien työllistymismahdollisuudet yliopiston ulkopuolelle ovat suomalaisiin tohtoreihin verrattuna perin heikot. Uraseurantakyselyyn vastanneista ulkomaalaisista ainoastaan joka kuudes oli työllistynyt yrityksiin ja lähes joka kolmas oli ollut työttömänä tohtoriksi valmistumisen jälkeen. (Sainio \& Carver 2016.)

Tohtorikoulutuspolitiikan yleismaailmalliset kehityslinjaukset ovat tehneet akateemiseen yhteisöön sosiaalistumisen yhä monimutkaisemmaksi ja ristiriitaisemmaksi, mikä näkyy esimerkiksi tohtoriopiskelijoiden identiteetin muodostamisen vaikeutena ja ristiriitoina (Archer 2008; Hakala 2009). Kilpailu rahoituksesta lisää epävarmuutta ja paineita. Tutkijan on jatkuvasti osoitettava kyvykkyytensä julkaisuin voidakseen lunastaa itselleen rahoitusta ja sen myötä tutkimustyön jatkuvuutta (Hakala 2009; Kouhia \& Tammi 2014). Paljolti juuri julkaisupaineisiin kulminoituu yhteiskuntatieteellisesti kasvatusta ja koulutusta tutkivien Kristiina Hannukaisen ja Kristiina Brunilan (2017) analysoima tohtorikoulutuksen tietokapitalistinen hallinta. Tämän päivän tohtoriopiskelijat eivät voi välttyä tempautumasta mukaan tietokapitalismin pyörteisiin ja joutumasta asemoimaan itsensä suhteessa sen eetokseen ja käytänteisiin, jotka monin osin ovat ristiriidassa perinteisten akateemisten arvojen kanssa. Tämä on omiaan luomaan alituista epävarmuutta omasta onnistumisesta, johon kirjoittajien mukaan tutkijakoulun arki ja tietokapitalistinen 


\section{ULKOMAALAISET J $\ddot{A} \ddot{A} V \ddot{A} T$}

SUOMALAISIA HERKEMMIN

ULKOPUOLIKSI

TIEDEYHTEISÖSS $\ddot{A}$.

hallinnan tapa juuri perustuvatkin (Hannukainen \& Brunila 2017).

Tuottavuuden ja suoritekeskeisyyden kulttuuriin sosiaalistuminen saattaa johtaa siihen, että tohtoriopiskelijat alkavat arvottaa tutkimusta sen taloudellisen hyödynnettävyyden perusteella (Mendoza 2007). Nyky-yliopistossa julkaiseminen - ennen kaikkea "oikeissa" journaaleissa - on käytännössä ainut tapa osoittaa tutkijan tehokkuus, laatu ja arvo (Guttorm ym. 2014; Hannukainen \& Brunila 2017). Publish or perish -kulttuurin tunkeutuminen tohtorikoulutukseen näkyy artikkeliväitöskirjojen ja yhteisjulkaisemisen lisääntymisenä myös pehmeillä aloilla (Kouhia \& Tammi 2014; Valo 2013; Hakkarainen, Hytönen, Makkonen \& Lehtinen 2013).

Tohtoriopiskelijoiden väitöstutkimukselleen antamia merkityksiä tutkineen Stubbin (2012) mukaan merkitykset vaihtelivat riippuen siitä, painottivatko opiskelijat lopputuotosta, prosessia vai molempia. Hän rinnastaa tohtoroitumisen merkityksen opiskeluorientaatiotutkimuksiin (esim. Mäkinen, Olkinuora \& Lonka 2004). Niiden taustalla on ajatus siitä, että opintoihin suuntaudutaan eri tavalla sen mukaan, painotetaanko itse opiskelua vai sen vaihtoarvoa. Tohtoroitumisen merkitys suuntaa opintojen aikana tehtäviä valintoja ja päätöksiä. Stubb pohtiikin tuottavuuskulttuurin mahdollista vaikutusta siihen, että moni suuntautui tohtoriopintoihin lopputuotosta ja sen tuomia mahdollisuuksia painottaen. Ne, jotka painottivat lopputuotosta, suuntautuivat jo uran alkuvaiheessa tulospainotteisesti ja omia saavutuksia korostaen. (Stubb 2012.)
Tohtoriopinnot mahdollistavat erilaisia tulevaisuuksia, ja koulutuksella on yhteiskunnallisia tavoitteita, mutta lisäksi yksilöillä on omat tavoitteensa. Tutkimuksessa (Vuolanto ym. 2006), jossa verrattiin koulutuspoliittisten dokumenttien tuottamaa kuvaa uranäkymistä tohtoriopiskelijoiden omiin kokemuksiin ja odotuksiin, tohtoriopintoihin suuntautuminen riippui osittain siitä, millaista uraa opiskelijat tavoittelivat ja millaisena he kokivat työllisyysnäkymät. Tohtoriopiskelijat arvioivat koulutuksen suuntaavan heitä yksipuolisesti akateemiselle uralle. Enemmistö opiskelijoista tavoittelikin akateemista uraa, mutta moni koki tutkijanuran mahdottomaksi kilpailun ja epävarmuuden lisääntyessä. Jatko-opiskelijoiden suuri määrä yliopistotyöpaikkoihin verrattuna ja ylikouluttautuminen huolestuttivat. (Vuolanto ym. 2006.) Samansuuntaisia tuloksia on saatu Yhdysvalloissa, jossa akateemisen uran tavoittelu väheni havahduttaessa opintojen aikana sen rankkuuteen ja vaativuuteen (Sauermann \& Roach 2012).

Ulkomaalainen tohtoriopiskelija on usein vieraassa kieli- ja kulttuuriympäristössä, jolla on oma sisäpiirin kieli, toimintatavat ja valtasuhteet. Ulkomaalaiset jäävät suomalaisia herkemmin ulkopuoliksi tiedeyhteisössä, jolloin kokemus tohtoroitumisesta saattaa muodostua erilaiseksi kuin kotimaassaan tohtoroituvilla (Cotterall 2015; Fotovatian 2012; Ugwu \& Adamuti-Trache 2017).

Tohtoriohjelmien nykyinen koulumaisuus saattaa hyödyttää Suomessa olevia ulkomaalaisia tohtoriopiskelijoita, sillä selkeän kurssiohjelman puuttumisen on osoitettu vaikeuttavan ulkomaalaisten integroitumista tiedeyhteisöön. Kurssimuotoisuus luo mahdollisuuksia vuorovaikutukselle, joka on tärkeää yhteenkuuluvuuden syntymiseksi (Fotovatian 2012). Ulkomaalaiset tohtoriopiskelijat suuntautuvat akateemiselle uralle ja suhtautuvat melko optimistisesti tulevaisuuden uraan sekä painottavat uranäkökulmaa opintojensa motiivina (Harman 2003; Sakurai ym. 2017), mutta arvioivat kieliongelmien heikentävän tulevaisuuden työnäkymiä (Ugwu \& Adamuti-Trache 2017). 
YDINTARINOITA PEILATTIIN

\section{KOKO AINEISTOSTA}

\section{MUODOSTETTUIHIN}

TEEMOIHIN.

\section{AINEISTO JA MENETELMÄT}

Tutkimuksen aineisto koostuu monitieteisen suomalaisen yliopiston humanistisen, yhteiskuntatieteellisen ja kasvatustieteiden tohtoriohjelmien tohtoriopiskelijoiden teemahaastatteluista $(\mathrm{N}=12)$, joiden avulla olemme pyrkineet saavuttamaan tutkittavien tohtoroitumiselle antamat merkitykset (Kvale 1996). Tieteenalat eivät ole kulttuureiltaan ja käytännöiltään homogeenisia, mutta emme ole päätyneet tarkentamaan kohderyhmän eroihin tieteenalatasolla vastaajien anonymiteetin suojelemiseksi.

Ulkomaalaisella tohtoriopiskelijalla tarkoitamme ulkomaalaisen opiskelijan statuksella tohtoriopintoja suorittavaa opiskelijaa. Suomalainen tohtoriopiskelija viittaa Suomen kansalaiseen. Jokaisesta kolmesta tiedekunnasta valittiin kaksi suomalaista ja kaksi ulkomaalaista, yhteensä kahdeksan naista ja neljä miestä. Kumpaakin sukupuolta edusti suomalaisissa ja ulkomaalaisissa yhtä monta opiskelijaa. Mukaan valittiin vähintään kaksi vuotta väitöskirjaansa valmistelleita opiskelijoita sen varmistamiseksi, että heille oli ehtinyt muodostua käsitys tohtoriksi opiskelusta. Vastaajien ikäjakauma ulottui 29 vuodesta 60 vuoteen, mediaani-ikä oli 36 . He rahoittivat opintojaan erilaisin rahoitusjärjestelyin.

Haastattelut toteutettiin teemahaastatteluina, joissa käsiteltiin seuraavia teemoja: tohtoroitumisen motiivit ja tavoitteet, tutkimuksen merkitys, tieteen ja yliopiston rooli ja arvot sekä oma rooli tiedeyhteisössä. Haastateltaville annettiin vapaus tuoda teemoista esiin haluamiaan asioita ja puhua itselle merkityksellisistä asioista tohtoroitumisen suhteen. Suomalaisia haastateltiin suomeksi ja ulkomaalaisia englanniksi, joka oli yhdelle haastateltavalle äidinkieli. Haastattelut kestivät puolesta tunnista hieman yli tuntiin. Anonymiteetin vuoksi haastateltavat nimettiin tiedekunnittain numeroin haastattelujärjestyksessä, ja suomalaisten vastauksista lainatuista sitaateista häivytettiin murreilmaisut.

Aineisto analysoitiin sisällönanalyysillä teemoitellen ja tyypitellen. Teemoittelun avulla aineisto selkiytettiin ja tiivistettiin (Eskola \& Suoranta 2003). Siitä muodostettiin 18 alateemaa, joihin ei yhdeksännen haastattelun analyysin jälkeen enää syntynyt uusia. Alateemat ryhmiteltiin seitsemään tohtoroitumista määrittävään merkityskokonaisuuteen, jotka nimettiin sisältöä kuvaten seuraavasti: akateemiset perusarvot, akateemisuuden legitimointi, kasvuprosessi, työ, tulevaisuuden epävarmuus, kilpailu ja yksilölliset tekijät.

Analyysiä jatkettiin pelkistämällä haastattelut eri haastatteluteema-alueista saatujen vihjeiden perusteella kolmeksi ydintarinaksi niiden sisällöllisten yhtäläisyyksien ja eroavaisuuksien perusteella. Ensimmäisessä tarinassa korostuivat selkeät tavoitteet tulevaisuuden suhteen ja päämäärätietoisuus, toisessa epävarmuus ja pelko ja kolmannessa tutkimusprosessiin keskittyminen ja tasapaino. Ydintarinoita analysoitaessa havaittiin, että uran tavoittelu, uranäkymät ja arviot itsestä suhteessa näihin suuntasivat sitä, mitä tohtoriopiskelija toi esiin tohtoroitumisensa kannalta merkityksellisenä.

Ydintarinoita peilattiin koko aineistosta muodostettuihin teemoihin ja niistä johdettuihin merkityskokonaisuuksiin (Ojala 2010), joiden pohjalta muodostettiin tyyppikuvaukset. Tyypit nimettiin sisällöllisen kerronnan mukaisesti seuraavasti: tieteellisen uran tavoittelija $(\mathrm{N}=6)$, kilpailun paineessa epäröijä $(\mathrm{N}=4)$ sekä itsellinen sivistyjä $(N=2)$. Ensimmäinen tyyppi tavoitteli selkeästi akateemista uraa, toinen hahmotteli erilaisia uravaihtoehtoja ja kolmas ei tavoitellut uraa lainkaan. Tyyppikuvaukset ovat ideaalityyppisiä todellisuuden kuvauksia, eikä yksikään tohtoriopiskelija yksinään edusta mitään ideaalityyppiä, vaan se muodostuu yhteen kootuista yksilöllisistä kertomuksista. 
TIETEELLISEN URAN

TAVOITTELIJAT PYRKIV ̈̈T

TEHOKKUUTEEN JA

HUIPPUSUORITUKSIIN.

\section{TOHTORIOPISKELIJATYYPIT}

Seuraavissa kuvauksissa analysoimme ja tulkitsemme, miten kukin ohtoriopiskelijatyyppi tohtoroitumiseen suuntautuu.

\section{Tieteellisen uran tavoittelija}

Tieteellisen uran tavoittelijoihin sisällytettiin viisi ulkomaalaista opiskelijaa ja yksi suomalainen. He olivat lähimpänä vastaajien 36 vuoden mediaani-ikää. Yliopistoura oli heille paljolti itsestäänselvyys ja tohtoroituminen välttämätön välitavoite ja pääsylippu akateemiseen yhteisöön, johon he vahvasti identifioituivat. He kuvasivat tohtoroitumista tutkijan perustutkinnoksi, mikä kannattaa suorittaa nopeasti, jotta voi jatkaa esimerkiksi post doc -tutkijana.

"Yritän luoda akateemista uraa. Akateeminen ura on organisoitu niin, että tohtorintutkinto on yksi taso, se on perusvaatimus ja siitä jatketaan eteenpäin." (Hum4)

"Se [tohtoroituminen] on se, mistä vasta alkaa se tutkijaura et sen takia sitä ei kannattais hirveesti pitkittää." (Yht2)

Tieteellisen uran tavoittelijat olivat pitkälti sisäistäneet nykyisen korkeakoulutuspolitiikan ideaalin tohtoroitumisesta ponnahduslautana tieteelliselle uralle, ei sen päätepisteenä. He tuntuivat omaksuneen kilpailun ja tehokkuusvaatimukset, vaikka kokivat ne jossain määrin ristiriitaisiksi tutkimustyön todellisuuden ja tavoitteiden kanssa. Tuottavuuspaineet hahmottuivat haasteina, joihin oli tartuttu päättäväisesti, jotta tavoitteet toteutuisivat. He tiedostivat kirkkaasti, että vain parhaat selviytyvät voittajina kiristyvässä kilpailussa ja pyrkivät parantamaan omia mahdollisuuksiaan olemalla tehokkaita ja tavoittelemalla huippusuorituksia. Tämä tarkoitti muun muassa artikkelien julkaisemista arvostetuissa kansainvälisissä julkaisuissa. Puheesta huokui vahva omistautuminen väitöskirjan tekoon, korkea työmoraali ja aikamme yliopistolle ominainen erinomaisuuden eetoksen korostus:

"Virallisesti työskentelen 65 lehtorina ja 35 tohtoriopiskelijana mutta luulen, että todellisuus on ennemminkin 100 ja 100. Elämäsi on se sinun työsi [--] sanotaan, että ollaksesi hyvä akateeminen tavallaan ajattelet, että ok minun täytyy julkaista paljon, ainakin yksi paperi vuodessa [--] sinulla on julkaisupaine koska siten sitä arvioidaan, mutta joskus se on ristiriidassa pitkien projektien kanssa, haluamme löytää jotain syvää etkä ehkä julkaise mitään [--] olet kuin sellainen tuotantokone." (Yht3)

"Pyrin työskentelemään erityisen ahkerasti varmistaakseni, että kaikki mitä esitän on parhaista parhainta [--]" (Kasv3)

"Olen julkaissut artikkeleita, tietenkin niiden pitää olla kansainvälisissä julkaisuissa ja toivottavasti hyvissä julkaisuissa tiedätkö.” (Yht4)

Kilpailun kovuus tuli esiin, kun tieteellisen uran tavoittelijat arvioivat tulevaisuuden uranäkymiään, joita omasta määrätietoisuudesta huolimatta sävytti epävarmuus. Tavoitteet olivat kyllä korkealla, mutta kireässä kilpailussa he näkivät mahdollisuutensa rajallisina aivan huipulle. Kansainväliset tohtoriopiskelijat kokivat kuitenkin ulkomailla suoritetun tutkinnon ja kansainvälisen kokemuksen tuovan lisäarvoa työllistymiseen.

"Haluan aina mennä hyvään yliopistoon, sellaiseen, jolla on kansainvälinen maine ja jos tavoitteeni on niin korkealla, tulen kohtaamaan rajua kilpailua. Tämän vuoksi olen alentanut odotuksiani ja menen yliopistoon, joka ei ole niin tunnettu." (Yht4)

"Jos haluat paremman työn, jos haluat olla kilpailun voittaja [--] etusija tässä kilpailussa menee niille, jotka ovat viettäneet ja asuneet joitain vuosia eri kulttuureissa [--].”(Hum3) 


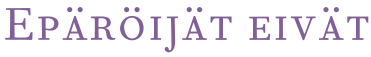

\section{USKALTANEET PANOSTAA}

\section{LIIKAA AKATEEMISEN}

URAN VARAAN.

Kunniainhimoisista tavoitteista huolimatta tieteellisen uran tavoittelijoiden tulevaisuutta varjosti huoli työllistymisestä, mikä ulkomaalaisilla liittyi kielitaitoon. Suomea taitamattomina he arvioivat työllistymismahdollisuutensa heikoiksi niin yliopistossa kuin sen ulkopuolellakin. He näkivät yliopiston ulkopuoliset työt sellaisina, joihin ei vaadittu korkeakoulu- saati tohtorintutkintoa.

”Jos työskentelet yliopistolla sinun täytyy puhua suomea tai ruotsia [--] olemme nykyään menettämässä tietynlaista taloudellista turvallisuutta ja mahdollisuutta työskennellä ja omistautua työllemme ajattelematta mitä seuraavana päivänä tapahtuu [--] Minulle tämä tarkoittaa joko yliopistoa, asema, jota kunnioitetaan tai siivoojaa tai pesulaa, jotka ovat muita vaihtoehtoja maahanmuuttajille, jotka eivät osaa puhua suomea." (Hum4)

Ylikouluttautumisuhan näki tosin myös tyypin ainoa suomalainen:

"Sitä puntaroi onko tästä oikeasti hyötyä vai haittaa. Oon ollu työpaikassa missä on haettu työntekijää ja sieltä otetaan suoraan tohtorit pois, koska ne on ylikoulutettuja. Et, jos haluaa virkamiesuralle niin niillehän riittää maisterikin.” (Yht2)

Tulevaisuuden epävarmuus korostui jatkuvina rahoitushakuina, jotka veivät aikaa tutkimustyöltä. Yksi ulkomaalainen näki suomalaisten olevan etulyöntiasemassa rahoitushakujen suhteen, mikä loi ylimääräistä suorituspainetta.

Yhtä lukuun ottamatta tieteellisen uran tavoittelijoilla ei ollut akateemisesti koulutettuja vanhempia. Kaksi ulkomaalaista halusi kuitenkin tohtoroitumisellaan tuottaa iloa ja kunniaa perheelleen:
"Olen perheessäni ensimmäinen, joka on päässyt näin pitkälle ja näen sen niin, että en opiskele itselleni vaan perheelleni. Ja äidilläni ei ole lainkaan koulutusta ja hänelle tämä on sellaista, mitä hän ei voinut tehdä. Oikeastaan, tämä on hänelle, hän on minun 'cheerleaderini'." (Kasv3)

Vanhempien kunniaksi opiskelun voidaan nähdä kytkeytyvän perheen matalaan koulutustasoon tai sosiaaliseen asemaan: tohtoriksi opiskelemalla opiskelija lunastaa ne uhraukset, joita vanhemmat ovat tehneet hänen koulutuksensa eteen. Sellaisten asioiden arvo yleensä korostuu, jotka eivät ole itsestäänselvyyksiä. Aiemmissa koululaisille ja heidän vanhemmilleen tehdyissä tutkimuksissa on tullut esiin, että maahanmuuttajilla on voimakkaampi koulutususko kuin valtaväestöllä, jolle koulutus on itsestään selvä oikeus (Kalalahti ym. 2017; Rinne \& Tuittu 2011).

\section{Kilpailun paineessa epäröijä}

Kilpailun paineessa epäröijiin luokittamamme opiskelijat olivat kaikki suomalaisia. Iältään he jakautuivat kahtia: kaksi oli kolmikymppisiä, kaksi yli 40-vuotiaita. Hekin olivat kiinnostuneita akateemisesta urasta, mutta eivät pitäneet sitä ainoana vaihtoehtona. Akateemisen uran kiinnostavuutta varjostivat sen rankkuus ja epävarmuus. Epäröijät näkivät akateemisen uran niin suurena riskinä, etteivät uskaltaneet panostaa liikaa sen varaan. Tohtoriksi opiskelu vaatii ponnistelua, mutta ei takaa uraa. Epäröijät olivat joko irtautuneet kokonaan yliopiston tehokkuusvaatimuksista tai tasapainoilivat vielä oman suhtautumisensa kanssa, jotta mahdollisuus akateemiselle uralle säilyisi. Samaan aikaan he pitivät ovea avoimena yliopiston ulkopuolisille uravaihtoehdoille. Akateeminen ura oli heille vain yksi vaihtoehto muiden joukossa.

"[--] loogisinta olis jatkaa niinku tutkimushankkeita [--] toisaalta mulla on laaja tuttavapiiri, mikä ei tuu akateemisen maailman kautta ja ne tietää, mitä sä osaat [--] et kaksjakosta toinen on tämä akateeminen ja toisaalta ihan muulla sektorilla [-mä oon aina niinku optimisti siinä mielessä, että mulle löytyy aina jotain hommii [--].” (Hum2) 
ITSELLISELLE SIVISTYJ ̈̈LLE

\section{TOHTORIOPINNOT OLIVAT}

\section{MAHDOLLISUUS UPPOUTUA}

TUTKIMUKSEEN JA SIVISTY Ä.

Epäröijien kerronnassa kuulsi suojautuminen epävarmuudelta, kun he pyrkivät olemaan ajattelematta tulevaisuutta ja keskittymään tähän hetkeen. $\mathrm{He}$ tunnustivat kilpailuun ja julkaisupaineisiin sopeutumisen yliopistouran jatkuvuuden kannalta välttämättömiksi, mutta voivat suhtautua niihin tieteellisen uran tavoittelijoita armollisemmin, kun kaikkia munia ei ollut aseteltu akateemiseen koriin eikä identiteettiä ollut rakennettu tieteen huipun tavoittelemiselle:

"En oo järin optimistinen sen suhteen, että jatkaisin yliopistolla ja se on poistanu stressiä hirveen paljon, kun mä oon tajunnu et mun ei välttämättä tarvii julkasta ihan koko ajan. Mun ei välttämättä ihan jatkuvasti tarvii tehdä itsestäni sellasta parasta mahdollista kandidaattia johonkin yliopistotyöhön [--] mä en välttämättä oo mikään sellanen tieteellinen tykki, mut sit taas olen silleen täysin pätevä akateemisen arkipäiväisyyden toimija. Pystyn ohjaamaan, pystyn opettamaan." (Hum1)

Yksi haastateltu koki tulevaisuutensa tutkijana suorastaan pelottavaksi ja tutkimustyön tehokkuusvaatimusten paineissa ristiriitaiseksi. Hän hahmotteli yhä omaa suhdettaan suorituspaineisiin. Niihin pitäisi vastata, jos mielii jatkaa akateemisessa maailmassa, mutta ei välttämättä, jos työllistyykin muualle.

"Tää ei oo ehkä semmonen, mihin tällä hetkellä pystyy täysin luottamaan, että tutkijana olo onnistuu, koska leikataan. Tavallaan pitää olla vähän niinku vaihtoehto a, b ja c. Ne muut vaihtoehdot, niissä ei välttämättä ole niin paljon merkitystä onko tohtori vai ei. Tutkijana oleminen eniten hyödyntää sitä koulutusta [--] Pelottaa tosi paljon. Mitään semmosii pitkäkestosia työsuhteita tällä alalla ei tehdä. Se painostaa jotenkin siihen kilpailuun, mitä tutkimuksessa itse ihmettelen, miten niinku luovuutta voi painostaa [--]." (Kasv1)

Kilpailun paineessa epäröijät näkivät koulutuksen ensisijaisesti valmistavan tutkijuuteen eikä yliopiston ulkopuolisin töihin. Tieteellisen uran tavoittelijan tavoin he näkivät tohtoroitumisen jopa haittaavan työllistymistä muualle. Yksi epäröijä koki kilpailuilmapiirin raunioittaneen yhteisöllisyyttä siinä määrin, että oli valmis tavoittelemaan mieluummin muuta kuin akateemista uraa.

"---] tääl on mun mielestä ihan valtavan huono ilmapiiri. Se huononee koko ajan ja tämmönen paranoian ja niinku tuhkatpäältä tunnelma [--] kyvyttömyys yhteistoimintaan oikeesti eikä vaan niinku et saadaan rahoitusta ja sit jokainen ottaa kaapista itelleen pikkusen sen oman toiminnan pyörittämiseen [--] ilmapiiri on suurin syy etsiä jotain muuta." (Hum2)

Se, että epäröijät olivat kaikki suomalaisia, vaikutti epäilemättä siihen, että he näkivät akateemiselle uralle vaihtoehtoja. Kotimaassaan tohtoriksi valmistuvien on todennäköisesti helpompi orientoitua muihinkin vaihtoehtoihin kuin määrätyksi ajaksi vieraaseen maahan tutkimusrahoituksen saaneiden ulkomaalaisten.

\section{Itsellinen sivistyjä}

Itsellisten sivistyjien suuntautuminen tohtoriopintoihin poikkesi kahdesta muusta tyypistä, sillä he eivät tavoitelleet tutkinnolla varsinaista työuraa. Toinen heistä oli suomalainen, toinen ulkomaalainen kasvatustieteiden tohtoriopiskelija. He olivat hyvin eri-ikäisiä, mutta eivät kumpikaan tutkimusjoukon nuorimmasta päästä. Tohtoroituminen merkitsi heille tutkimukseen uppoutumisen lisäksi itsensä kehittämistä, henkistä kasvua - sivistystä. Pääasialliseksi tavoitteekseen he kokivat oppimisprosessista nauttimisen. 


\section{TOHTORIOPISKELIJA KÄY}

\section{JATKUVAA AKATEEMISEN}

\section{TULEVAISUUDEN JA YLIOPISTON \\ ULKOPUOLISEN URAN V ̈̈LIST $\ddot{A}$}

IDENTITEETTINEUVOTTELUA. semmosta vaikuttajaa ja akateemiseen yhteisöön osallistujaa niin semmosta mä en oo täyttänyt." (Kasv2)

Itsellinen sivistyjä haki tohtorin tutkinnolla myös uskottavuutta ja oman asiantuntijuuden legitimointia. Hän ei kuitenkaan ilmaissut tarvitsevansa legitimointia akateemisessa maailmassa etenemiseen kuten tieteellisen uran tavoittelija vaan käytti tohtoroitumista lähinnä välineenä saada äänensä kuuluviin.

”[-- merkityksellisintä läpi koko tohtoriopintojen [--] itse tutkimusprosessi [--] Ajattelen, että laadullisen tutkimuksen kautta tutkija voi muuttaa itseään. Se on merkityksellisintä. Voin olla parempi ihminen. Voin tulla uudeksi ihmiseksi oman tutkimukseni kautta [--] sen prosessin kautta tutkija kasvaa paljon, kuten lapsi kasvaa joka päivä [--]."(Kasv4)

Itselliset sivistyjät tiedostivat yliopistomaailman lisääntyvän kilpailullisuuden, julkaisemisen pakon ja ammattimaisuuden realiteetteina, mikäli mieli tehdä akateemista uraa, mutta tekivät niihin henkilökohtaisesti selkeän pesäeron. He eivät kokeneet niiden rajoittavan itseään, koska uran tavoittelu oli toissijaista.

"Kilpailullinen ilmapiiri ei häiritse minua, mutta periaatteessa kukaan ei ole vapaa kilpailulta modernissa yhteiskunnassa [--] jos tähtää professoriksi olen sitä mieltä, että pitäisi ajatella tällaisia asioita [julkaisemista] koko ajan. Jos haluan jäädä yliopistolle [--] sitten minun pitäisi ajatella tätä koko ajan [--] nykyajan yliopistosta on yhä enemmän tulossa työharjoitteluinstituutti. Surullinen tilanne." (Kasv4)

Toinen itsellinen sivistyjä opiskeli työnsä ohella, mikä selittää osittain huoletonta suhtautumista julkaisupaineisiin.

"Se [tohtoroituminen] tuo lisäarvona sitä asiantuntijauskottavuutta. Mun sanoilla on enemmän painoarvoo. Mä luulen et mä tarviin sitä [--] Ehkä odotuksia tuli siihen, että olisi pitänyt tehdä jotain julkaisuja ja niitä mä en oo tehny [-ehkä on odotettu enemmän jo ennen väitöstä

\section{ONKO TOHTORIKOULUTUKSESSA TILAA ERILAISUUDELLE?}

Analyysimme ja tulkintamme osoittavat, kuinka heterogeeninen joukko tohtoriopiskelijoita opiskelee yhä homogeenisemmassa tohtorikoulutusjärjestelmässä. Haastateltujen käsitykset sisältävät runsaasti ristiriitaisuuksia suhteessa tohtorikoulutukselle asetettuihin, korkeakoulu- ja tiedepolitiikasta johdettuihin virallisiin tavoitteisiin ja niiden ympärille rakentuvaan diskurssiin ja retoriikkaan (ks. myös Hannukainen \& Brunila 2017; Kouhia \& Tammi 2014). Niissä korostetaan erinomaisuutta, kärkihankkeita, huippuyksiköitä sekä kansainvälistymisen tuottamaa verkostoitumispotentiaalia ja kulttuurista moninaisuutta. Kuten aiemmissa tutkimuksissa (esim. Hakala 2009; Hannukainen \& Brunila 2017; Vuolanto ym. 2006; Sauermann \& Roach 2012), tutkimuksemme kohteena olleiden tohtoriopiskelijoiden todellisuutta ja tulevaisuuden näkymiä sävyttivät paljolti kilpailu, epävarmuus ja tutkinnon heikko työelämävastaavuus.

Tohtoriopiskelijat ovat toki hyvin tietoisia politiikan määrittelemästä ideaalitohtoroitujan mallista sensä suhteessa siihen. Haastatteluissa nousi esiin, miten tohtoroituminen merkitsi jatkuvaa akateemisen tulevaisuuden ja yliopiston ulkopuolisen uran välistä identiteettineuvottelua (Ylijoki \& Ursin 2013). Näin kokivat jopa tieteellisen uran tavoittelijat, jotka määrätietoisesti tähtäsivät akateemiselle uralle. Paradoksaalisesti itsellisillä sivistyjillä minän suhde ulkoisiin vaatimuksiin ja paineisiin oli kaikkein tasapainoisin heidän astuessaan ikään kuin marginaalin asemaan. ja joutuvat jatkuvasti tasapainoillen asemoimaan it- 


\section{YHTEISÖLLISYYS}

\author{
VAIKUTTAA OSITTAIN \\ KADOTETULTA.
}

Lähinnä tohtoriopiskelijaideaalia ovat ulkomaalaiset tohtoriopiskelijat, jotka suuntautuvat suomalaisia märätietoisemmin akateemiselle uralle sovittautumalla muottiin. Suuntautumista selittää todennäköisesti se, että heille yliopiston ulkopuoliset uranäkymät ovat suomalaisia heikommat. Yliopistomaailma edustaa tohtoriopiskelijoille yhteisiin universaaleihin perusarvoihin nojaavaa kansainvälistä tilaa, missä oma asema voidaan legitimoida. Tohtoroituminen avaa pääsyn "akateemiseen kuplaan", akateemiselle kentälle, jolla toimimiseen tohtorin tutkinto tuottaa tarvittavia resursseja ja arvostettuja pääomia (Bourdieu \& Wacquant 1992). Näiden avulla tuore tohtori voi ainakin yrittää kilpailla harvoista akateemisista työpaikoista, mutta ne eivät auta luovimaan vieraan maan ei-akateemisilla työmarkkinoilla.

Kansainvälisyys on tieteessä ja tohtorikoulutuksessa itsestäänselvyys mutta myös status- ja mainetekijä, toisinaan jopa kritiikittömästi laadun mittari. Ulkomaalaisten tohtoriopiskelijoiden kokemukset raottivat osaltaan sitä todellisuutta, mitä saattaa kätkeytyä kansainvälisyydellä kiillotettujen kulissien taakse. Ulkomaalaisten tohtoriopiskelijoiden omat tavoitteet jäävät herkästi virallisten tavoitteiden varjoon (esim. Cotterall 2015), mikä näkyi myös tässä tutkimuksessa.

Ulkomaalaiset tohtoriopiskelijat joutuvat kohtaamaan samat työelämäuhat kuin maahanmuuttajat yleensä (esim. Kyhä 2011): ajautuminen koulutusta vastaamattomaan työhön Suomessa, ellei ura avaudu yliopistomaailmassa. Käytetäänkö opiskelijoita korkeakoulutuksen kansainvälistymisstrategian välineinä tarjoamatta vastineeksi koulutusta vastaavaa tulevaisuutta? Kansainvälistymisproblematiikkaa tulisi tutkia lähemmin, jotta ulkomaa- laisten tohtoriopiskelijoiden potentiaali voitaisiin hyödyntää heitä itseään ja suomalaista yhteiskuntaa ja korkeakoulutusta palvelevalla tavalla. Samalla on muistutettava, että epävarmuus tulevaisuudesta koskee myös suomalaisia. Yhteiskuntatieteilijä Johanna Hakalan (2009) esittämä huoli siitä, että lahjakkaat tutkijat lähtevät yliopistosta on osoittautunut osittain aiheelliseksi.

Kuten ideaalityypittelyssä yleensäkin, luonnostelemamme tyypit eivät ole kategorisia. Niissä on sekä eroja että yhteneväisyyksiä. Vapauden ja yhteisöllisyyden kaltaiset akateemiset perusarvot ovat kaikille tärkeitä. Tutkijan työtä kuvataan totuuden etsimiseksi, eettisyydeksi ja kriittisyydeksi. Samasta, akateemisen identiteetin kovasta ytimestä kertovat aiemmatkin tutkimukset (esim. Hakala 2009; Henkel 2004). Yhteisöllisyys vaikuttaa osittain kadotetulta, kun haastattelemamme tohtoriopiskelijat viittasivat siihen entisaikojen ideaalina. Tämä kuvastaa yliopistoa kuviteltuna tilana (Clegg 2008). Aikaa perinteisiin keskusteluihin tiedeyhteisössä on harvoin, mitä on kuvattu ajattoman ajan kaipuuksi (ks. Ylijoki \& Mäntylä 2003). Yhteisöllisyyttä rajoittavat lisääntyvä tuotosten mittaaminen sekä tohtoriopiskelijoiden keskinäinen kilpailu, minkä tilalle toivotaan yhteisöllistä kilpailua.

Jaettuja olivat myös käsitykset pehmeiden tieteiden eriarvoisesta asemasta. Monipuolisen tiedon tuottamista arvostettiin, mutta ympäristön koettiin arvostavan muunlaista tietoa. Tämä näkyi rahoituksessa, jonka nähtiin suosivan koville tieteille ominaisia, taloudellisesti merkityksellisiä ja innovatiivisia tutkimusaiheita, mikä on omiaan ohjaamaan tohtoriopiskelijoiden suuntautumista (ks. Kouhia \& Tammi 2014).

Yksi tämän päivän tohtoriopiskelijoita erilaistava tekijä on ikä ja siihen usein liittyvä erilainen elämäntilanne (myös Rauvola \& Silvennoinen 2017). Nelikymppisiä tai sitä vanhempia oli tutkimuksessamme viisi, ja ainoastaan kolme vastasi iältään tohtorikoulutuksen koulutuspoliittista ideaalia. Nuoruutta, nopeutta ja kansainvälisyyttä painottavan tohtorikoulutuspolitiikan varjossa tuhannet tohtoriopiskelijat tekevät edelleen väitöstutkimuksiaan sivistyäkseen, omaan tahtiin, työn 
ohella, usein akateemisen yhteisön ulkojäseninä. He muistuttavat paljolti aikuisopiskelijaa sen perinteisessä mielessä. Tohtoroitumiseen valikoitumista suurilla tilastoaineistoilla tutkineet Arto Jauhiainen ja Hanna Nori (2017) erottivat ryhmän "pitkän linjan puurtajat", joka muistutti taustoiltaan tällaisia tohtoriopiskelijoita, samoin kuin tämän tutkimuksen itselliset sivistyjät.

Opiskelijoiden moninaisuuden keskellä ei voi olla kysymättä, missä mitassa vallitseva, yhä koulumaisempi, yhdenmukaiseen ammattitutkijuuteen tähtäävä tohtorikoulutuksen one size fits all -muotti tarjoaa tilaa nyt ja tulevaisuudessa erilaisille ja eri-ikäisille tohtoriopiskelijoille. Missä määrin se sietää luovuudelle ja innovatiivisuudelle elintärkeää toisin toimimista ja erilaisuutta ilman, että ne sysätään marginaaliin?

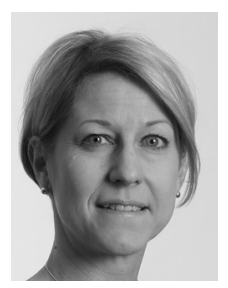

MARJA PEURA

KM, tohtorikoulutettava

Kasvatustieteiden laitos

Turun yliopisto

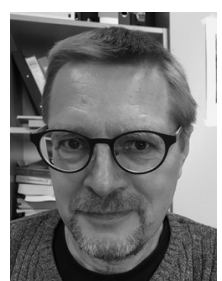

ARTO JAUHIAINEN

$\mathrm{KT}$, professori

Kasvatustieteiden laitos

Turun yliopisto

\section{LÄHTEET}

Aittola, H. (1995). Tutkimustyön ohjaus ja ohjaussuhteet tieteellisessä jatkokoulutuksessa. Jyväskylä Studies in Education, Psychology and Social Research 111. Jyväskylä: Jyväskylän yliopisto.

Aittola, H. \& Määttä, P. (1998). Tohtoriksi tutkijakoulusta. Tutkijakoulut tieteellisten jatko-opintojen uudistajina. Koulutuksen tutkimuslaitos. Tutkimuksia 3. Jyväskylä: Koulutuksen tutkimuslaitos.

Archer, L. (2008). The new neoliberal subjects? Young/ er academics' constructions of professional identity. Journal of Education Policy 23 (3), 265-285.

Becher, T. (1989). Academic Tribes and Territories: Intellectual Enquiry and the Cultures of Discipline. Milton Keynes: The Society for Research into Higher Education ja Open University Press.

Bourdieu, P. \& Wacquant, L. J. D. (1992). An Invitation to Reflexive Sociology. Cambridge: Polity Press.

Clegg, S. (2008). Academic identities under threat? British Educational Research Journal 34 (3), 329-345.

Cotterall, S. (2015). The rich get richer: international doctoral candidates and scholarly identity. Innovations in Education and Teaching International 52 (4), 360-370.

Eskola, J. \& Suoranta, J. (2003). 6. painos. Johdatus laadulliseen tutkimukseen. Tampere: Vastapaino.

EU (2020). EU 2020 strategy. http://eur-lex. europa.eu/LexUriServ/LexUriServ.do? uri = COM:2010:2020:FIN:EN:PDF (8.3.2017).
Fotovatian, S. (2012). Three constructs of institutional identity among international doctoral students in Australia. Teaching in Higher Education 17 (5), 577-588

Guttorm, H., Arvola-Orlander, A., Niemi, A-M., Vaahtera, E., Mertanen, K., Tammi, T., Mononen-Batista Costa, S., Brunila, K., Kouhia, A., Paakkari, A., Kainulainen, V. \& Ikävalko, E. (2014). Akateeminen kapitalismi ja kollektiivisuuksien paradoksaalisuudet tohtorikoulutuksessa. Aikuiskasvatus 34 (2), 121-128.

Hakala, J. (2009). The future of the academic calling? Junior researchers in the entrepreneurial university. Higher Education 57 (2), 173-190.

Hakkarainen, K., Hytönen, K. Makkonen, J. \& Lehtinen, E. (2013). Kollektiivista mallia voidaan soveltaa kasvatustieteiden tohtorikoulutuksessa. Aikuiskasvatus 4 (33), 277-289.

Hannukainen, K. \& Brunila, K. (2017). "Jokainen verissä päin sitä omaa edistää". Tutkijakoulutus, tieto ja tutkijuus tietokapitalismissa. Aikuiskasvatus 37 (2), 96-107.

Harman, K. (2003). International PhD students in Australian universities: financial support, course experience and career plans. International Journal of Educational Development 23 (3), 339-351.

Henkel, M. (2004). Current science policies and their implications for the formation and maintenance of academic identity. Higher Education Policy 17 (2), 167-182. 
Hiltunen, K. \& Pasanen, H.-M. (2006). Tulevat tohtorit. Jatko-opiskelijoiden kokemukset ja arviot tohtorikoulutuksesta 2005. Opetusministeriön julkaisuja 2006:48.

Husso, K. (2005). "Tohtorit, tiedepolitiikka ja työmarkkinat - Tutkijankoulutus Suomessa 1950-luvulta tutkijakoulujen aikaan". Opetusministeriön julkaisuja 2005:21

Isohätälä, J., Louis, J.N., Mikkola, K. \& Pyhältö, K. (2017). Towards a doctoral degree and future career - perceptions of doctoral students at the university of Oulu. Acta Univ. Oul.F.12. Oulu: University of Oulu.

Jauhiainen, A. \& Nori, H. (2017). Puurtajat, Statuksen korottajat ja Koulutuspääoman uusintajat: Tohtoriopiskelijat ja heidän taustansa suomalaisella yliopistokentällä. Kasvatus 48 (2), 80-95.

Kalalahti, M., Varjo, J., Zacheus, T., Kivirauma, J., Mäkelä, M.-L., Saarinen, M. \& Jahnukainen, M. (2017). Maahanmuuttajataustaisten nuorten toisen asteen koulutusvalinnat. Yhteiskuntapolitiikka 82 (1), 33-44.

Kehm, B. M. (2007). Quo vadis doctoral education? New European approaches in the context of global changes. European Journal of Education 42 (3), 307-319.

Kouhia, A. \& Tammi, T. (2014). Akateemisen kapitalismin uusliberaali tutkijasubjekti kasvatustieteellisessä tohtorikoulutuksessa. Kasvatus \& Aika 8 (2), 22-39

Kvale, S. (1996). InterViews: An Introduction to Qualitative Research Interviewing. Lontoo: Sage.

Kyhä, H. (2011). Koulutetut maahanmuuttajat työmarkkinoilla. Tutkimus korkeakoulututkinnon suorittaneiden maahanmuuttajien työllistymisestä ja työurien alusta Suomessa. Turun yliopiston julkaisusarja C, osa 321. Turku: Turun yliopisto.

Laiho, I. (1997). Mestareiden opissa. Tutkijakoulutus Suomessa sotien jälkeen. Koulutussosiologian tutkimuskeskus. Raportti 42. Turku: Turun yliopisto.

Maunula, M. (2014). Perheellisen naistohtoriopiskelijan arki, elämänkulku ja tulevaisuusajattelu. Väitöskirja. Jyväskylä: Jyväskylän yliopisto, Kokkolan yliopistokeskus Chydenius.

McAlpine, L. \& Turner, G. (2012). Imagined and emerging career patterns: perceptions of doctoral students and research staff. Journal of Further and Higher Education 36 (4), 535-548.

Mendoza, P. (2007). Academic capitalism and doctoral student socialization: A case study. The Journal of Higher Education 78 (1), 71-96.

Mäkinen, J., Olkinuora, E. \& Lonka, K. (2004). Students at risk: Students' general study orientations and abandoning/prolonging the course of studies. Higher Education 48 (2), 173-188.
Niemi, H., Aittola, H., Harmaakorpi, V., Lassila, O., Svärd, S., Ylikarjula, J., Hiltunen, K. \& Talvinen, K. (2011). Tohtorikoulutuksen rakenteet muutoksessa. Tohtorikoulutuksen kansallinen seuranta-arviointi. Korkeakoulujen arviointineuvoston julkaisuja 15:2011. Helsinki: Korkeakoulujen arviointineuvosto.

Ojala, H. (2010). Opiskelemassa tavallaan. Vanhat naiset ikäihmisten yliopistossa. Tampere: Tampere University Press.

OKM (2015). Ehdotus yliopistojen rahoitusmalliksi 2017 alkaen. Opetus- ja kulttuuriministeriön työryhmämuistioita ja selvityksiä 2015:19.

OKM (2016). Tutkijanuran tilannekuva. Tutkijanuratyöryhmän loppuraportti. Opetus- ja kulttuuriministeriön julkaisuja 2016:2.

OKM (2018). Tiede- ja tutkimus. http://minedu.fi/tiedeja-tutkimus (1.1.2018).

OPM (2004). Yliopistotilastot 2003. Taulukoita KOTA-tietokannasta. Opetusministeriön julkaisuja 2004:24.

Peura, A. (2008). Tohtoriksi tulemisen tarina. Kasvatustieteenlaitoksen tutkimuksia 219. Helsinki: Helsingin yliopisto.

Pritchard, R. (2004). Humboldtian values in a changing world: staff and students in German universities. Oxford Review of Education 30 (4), 509-528.

Rauvola, J. \& Silvennoinen, H. (2017). Yhteisöllisyys ja osallisuus tieteellisessä jatkokoulutuksessa. Teoksessa Toom, A., Rautiainen, M. \& Tähtinen, J. (toim.). Toiveet ja todellisuus - Kasvatus osallisuutta ja oppimista rakentamassa. Jyväskylä: Suomen kasvatustieteellinen seura, 365-393.

Rinne, R. \& Jauhiainen, A. (2012). In the shifting sands of policy - University academics' and employees' views and experiences of Finland's new higher education policy. Teoksessa Ahola, S. \& Hoffman, D. (toim.) Higher education research in Finland: Emerging structures and contemporary issues. Jyväskylä: Finnish Institute for Educational Research, 89-110.

Rinne, R. \& Tuittu, A. (2011). Peruskoulu maahanmuuttaja- ja suomalaisvanhempien silmin. Teoksessa Klemelä, K., Tuittu, A., Virta, A. \& Rinne, R. (toim.) Vieraina koulussa? Monikulttuurinen koulu oppilaiden, vanhempien, opettajien ja rehtoreiden kokemana. Turku: Turun yliopiston kasvatustieteiden tiedekunta, 97-157.

Sainio, J. \& Carver, E. (2016). Tavoitteidensa mukaisella työuralla. Aarresaari-verkoston tohtoriuraseuranta 2015, vuosina 2012-2013 valmistuneet. https:// www.aarresaari.net/uraseuranta/julkaisut (5.1.2018).

Sakurai, Y. (2014). Understanding Factors Contributing to the Academic Engagement of International University Students. Studies in educational sciences 259. Helsinki: University of Helsinki. 
Sakurai, Y., Vekkaila, J. \& Pyhältö, K. (2017). More or less engaged in doctoral studies? Domestic and international students' satisfaction and motivation for doctoral studies in Finland. Research in Comparative and International Education 12 (2), 143-159.

Sariola, H. (2017). Iso pyörä "uudistaa" tohtorikoulutusta, mutta miten... http://blogs. helsinki.fi/med-viikonjuttu/author/hvsariol (22.5.2017).

Sauermann, H. \& Roach, M. (2012). Science PhD Career Preferences: Levels, Changes and Advisor Encouragement. PloS ONE 7 (5): e36307. http:// journals. plos.org/plosone/article?id = 10.1371/ journal.pone.0036307 (2.1.2018).

Seuri, A. \& Vartiainen, H. (2018). Yliopistojen rahoitus, kannustimet ja rakennekehitys. Kansantaloudellinen aikakauskirja 114 (1), 100-131.

Slaughter, S. \& Leslie, L.L. (1997). Academic capitalism: Politics, Policies, and the Entrepreneurial University. Baltimore/London: The Johns Hopkins University Press.

Stubb, J. (2012). Becoming a scholar. The dynamic interaction between the doctoral student and the scholarly community. Doctoral dissertation. Research Report 336. Helsinki: University of Helsinki.

Suomen Akatemia (2011). Tavoitteeksi laadukas, läpinäkyvä ja ennakoitava tohtorikoulutus. http://www.aka.fi/globalassets/awanhat/ documents/tiedostot/liitetiedostot/tohtorikoulutus_ joulukuu_2011.pdf (16.9.2016).
Trow, M. (1973). Problems in the Transition from Elite to Mass Higher Education. Berkeley, CA: Carnegie Commission on Higher Education.

Ugwu, D. \& Adamuti-Trache, M. (2017). Post-graduation plans of international science and engineering doctoral students attending U.S. universities. Journal of International Students 7 (1), 1-21.

Valo, M. (2013). Monografia vai artikkeliväitöskirja? Yliopistopedagogiikka 20 (1), 25-27. https://lehti. yliopistopedagogiikka.fi/2013/04/08/monografia-vaiartikkelivaitoskirja (27.12.2017).

Vipunen (2017a). Opiskelijat ja tutkinnot. https:// vipunen.fi/fi-fi/yliopisto/Sivut/Opiskelijat-ja-tutkinnot. aspx (22.12.2017).

Vipunen (2017b). Kansainvälisyys. https://vipunen.fi/fi-fi/ yliopisto/Sivut/Kansainvälisyys.aspx (27.12.2017).

Vuolanto, P., Pasanen, H.-M. \& Aittola, H. (2006). Employment of PhDs in Finland. Prospects and expectations of doctoral students. VEST: Journal of Science and Technology Studies 19 (1-2), 31-56.

Ylijoki, O.-H. \& Mäntylä, H. (2003). Conflicting time perspectives in academic work. Time \& Society 12 (1), 55-78.

Ylijoki, O.-H. \& Ursin, J. (2013). The construction of academic identity in the changes of Finnish higher education. Studies in Higher Education 38 (8), 1 135-1 149. 